\title{
Resolution of Objective Conflicts of History Education
}

\author{
Enxing $\mathrm{He}^{1, \mathrm{a}}$
}

\author{
${ }^{I}$ Nanjing Foreign Language School IB \\ a*Corresponding author. Email: 2645018124@qq.com
}

\begin{abstract}
The conflict between various objectives of history education has always been a great concern for scholars and educators all over the world. For years, experts in this field have been studying and researching for education methodologies as the solution to the problem. This paper focuses on the topic with an explanation to what are the main goals or objectives of history education to both the nation and the learners or the society and why achieving the goals is essential to not only the education field but also other non-academic fields of inquiry. With analysis from different perspectives, the importance of history education to the society and nation is clearly illustrated and acts as the basis for the later investigation. Next, the reasons for conflicts and problems to emerge are discussed in this paper as well. The concept of ethics, politics, religions, and nationalism are included as factors influenced or represented by history education. The conflict between individual critical thinking and social or national unity is brought to the discussion and directly leads to the next part. Finally, with the example of European countries, North Ireland, Britain, and Ukraine especially, this paper combines various scholars' research and ideas to the problem and reach out a conclusion of the best education methodology of history.
\end{abstract}

\section{Keywords: Objective conflicts, History education, Education methodologies, Constructivism}

\section{INTRODUCTION}

With the long-time debate over history teaching and learning methodologies together with the profound characteristics of historical knowledge, history education has a complex educational system combined with political, ethical, religious disciplines. What exactly is expected to be taught by the teacher and learned by the students from the past and whether various teaching methodologies can successfully achieve the goal of history education have been continuously discussed by scholars from different regions and periods. Indeed, the problem of history education is encountered by learners all around the world. Students are often taught with colored or reshaped history knowledge constructed by the nation. The goal of history education of educating students to gain better independent, ethical interpretation ability and the government's goal of constructing the students' national and social identity through history education is thus proved to have explicit conflicts. In this research, the topic will mainly focus on the current situation and problem derived from the conflicts and discuss the solution to balance the two goals of history education. Achieving the two main goals, illustrated by numerous scholars before, brings out great influence on the individual, society, and nation. Learning the past helps students build identity and personality during the process of interpreting historical events ethically. At the same time, it contributes to constructing the students' national identity and social conformity. It provides the students with a perspective of their society and nation over a series of historical events that influenced or shaped the current living situation. An efficient education methodology for history should have the ability to not only deliver the historical facts to the students but also offer them a way to develop a deeper understanding of their own towards the past to draw a conclusion from the past and make a logical assumption for the future.

\section{THE IMPORTANCE OF ACHIEVING THE GOALS OF HISTORY EDUCATION}

History education contains knowledge constructed by the historians obtained through studying into the past with evidence of historical events, deriving academic and professional judgment or reflection from the evidence, and reaching a conclusion of the relationship between an array of events to reveal specific discipline for history development and potential. For various 
aspects and fields, no matter academic or non-academic, the potential knowledge or values obtained from history education play a great role in constructing the basis for the formation of new knowledge.

For students to obtain a level of ethical interpretation ability, 'history education literature has paid enough attention to what ethics is and does as a discipline' [4]. History knowledge, consist of both historical facts and historical narrative and combines the objectivity of facts and subjectivity derived from the ideas expressed by historians from different positions and perspectives. Just because of the inevitable subjectivity of knowledge in historical narratives, students with active thinking ability are expected to derive personal understanding through discussion over past events and history knowledge.

The unique characteristics of history should be able to provide a precious practice for the students to improve self-thinking and ethical evaluating or interpreting skills. Their ability to judge the ethical values behind historical events enables them to develop an understanding system with their believing disciplines and values which later ensures they make the 'correct' ethical choices from their perspectives. At the same time, the goal of history education may be considered from the nation's perspective. According to Korostelina, 'history education is one of the most important mechanisms in the continuing process of the establishment of the modern nation-state' [7]. Since the way historical facts are presented and interpreted by textbooks or articles directly influence the way students construct their social and national identity, the national government wishes to achieve the goal of social cohesion by utilizing 'mechanisms employed by state-controlled history textbooks to shape several aspects of national identity [7]. Obtaining an identical system of social, ethnic, and national values from a uniform understanding of national history for every educated citizen ensures they gain an overview of how their country was developed chronologically. This overview later correlates to a better understanding of the people of a nation's political structure, government policies, and current national living conditions. In this way, citizens naturally develop a more confirm sense of loyalty to the country and willing to take more responsibility and obligation in protecting their own country morally.

In conclusion, history education with the goal of both developing students' moral and ethical evaluation or interpretation level and constructing a uniform national identity for the whole society are expected to be achieved through efficient education methodology. With the accomplishment of these two goals, the society will be potentially ideological with a relatively high average level of ethical understanding of citizens and at the same time great loyalty, respect, and trust to the country they're living in.

\section{POTENTIAL PROBLEMS OR CONFLICTS THAT LIMIT THE EFFECTIVENESS OF HISTORY EDUCATION}

Though history education may be important to different fields of inquiry-based on achieving its goals, potential problems and conflicts derived from the process of attempting to obtain the aims hinder this academic discipline from achieving its greatest potential influence. "There are tensions between political ideology and history education", as Maitland Stobart stated [11]. According to Stobart, any country's history with the existence of violence, battles, wars, and other forms of conflict may reveal the implicit injustice caused by a nation's choices and actions in the past.

To keep up with the national goal of obtaining social cohesion, the government keeps adjusting the education system in correlation. Nation-controlled curricula, especially history education, maybe reshaped by the country from a nation's perspective and subjective tone of describing the past events. From Alasdair MacIntyre's point of view, the "educated public" should have the ability and the right to "open its discoveries and debates to the introduction of new points of view and the opening up of new possibilities" [10]. However, with the government's effort to create social and national unity, conflicts and violence are intended to be avoided in the curricula. And history education, with potentially the most explicit expression of the injustice of the country's past, is reshaped and colored with subjective historical narrative from the country's perspective. The term historical "revisionism" which is used to describe the action of changing the way historical facts or narratives are interpreted to achieve a specific modern political ideology further illustrates and explains this problem.

The attempt to revise the original view, theory, and knowledge leads to the threat of applying over-colored and uncritical historical narratives in history education. One example of the explicit problem of revised history education is stated and described by Margaret Eastman Smith that in the 20th century, in North Ireland. History education was revised into such an extremely nationalistic version that the teacher suffered from teaching the colored history to students and refused to merely follow the set curriculum [11]. North Ireland was not the only country that experienced the problem of historical revisionism, the similar situation also happened in Ukraine. According to Karina Korostelina, Ukraine as a relatively new nation aims at constructing and strengthening the national and social identity to ensure social cohesion and unity. To achieve this goal, the government sets history education curricula to obtain knowledge that "emphasizes the idea of victimhood as 
the core of national identity and posits Russia as an oppressive and aggressive enemy" [7].

North Korea may also have a revised history education since Korostelina stated that the history textbooks for the curriculum emphasized the greatness of the nation throughout history and exaggerated the role of national leader Kim II Sung [5]. The deliberately reshaped and revised history for conflicts in the country's past to achieve the government goal of social unity greatly affects and hinders the first goal of history education of educating the students to gain a personal ethical understanding system to be achieved. With the intended and authoritative interpretation of historical events and facts, students can barely develop personal understanding or raise any questions about the controlled past of the country. The practical conflict between unity and individual, or the uniform social identity and individual ethical values and critical thinking, has been discovered in different corners of the world by scholars. It then leads to the question of what is the most suitable methodology for history education in regard to the inevitable characteristic of history education - nation-controlled for achieving the national and social goals, but at the same time try to reserve the ability and the right for students to critically think and interpret over historical facts.

\section{METHODOLOGIES TO BALANCE THE TWO GOALS AND SOLVE THE CONFLICT}

For years, different nations, or the scholars in the countries, have been adjusting their history education curricula according to various theories. Scholars from all over the world have also been investigating and researching for suitable history education methodologies to balance between the aforementioned goals. Among all the theories or practical investigation of methodologies, though many of them are similar to each other, there are clear differences between methodologies that are suitable for different countries. This study will then list several commonly mentioned and utilized methodologies, conclude the most essential and core characteristics of them, and suggest the way they may be combined and utilized to make a balance between history education goals in a global perspective.

\subsection{Constructivism}

Constructivism, a specific education theory that encourages learners to construct their own understanding and combine their thoughts and ideas with what's taught to them, has been one of the most commonly studied, researched, and utilized theories for countries and scholars. Except for the special effects to learners, this theory also requires the teachers, or instructors, to act as facilitators to conduct the knowledge to learners instead of offering authoritative and unquestionable interpretation to foster learners' independent reflecting skills [12]. This theory explicitly consists of the first goal of history education which aims at educating the students with their own ethical, political, religious critical thinking system. Because of this, education experts and regulators from different countries and time periods have tried to apply this theory to their national curricula. For example, according to Hilary Cooper, the British national curriculum for history was set with constructivism, and content was explored through the process of historical inquiry during the 1970s and 1980s [6]. The innovated history education curriculum set four requirements for the content taught to the students: First, 'understanding the varying status of sources'; second, 'making suggestions based on evidence of how people in societies with different knowledge bases and belief systems from our own may have thought and felt'; third, 'selecting and combining inferences in order to construct accounts of changes over time; and last, 'understanding why accounts may be equally valid but different' [6].

Constructionists emphasize objectivity in history education by introducing the concept of similarities and differences, perspectives and interests, individuals and groups to the learners. Applying this theory to history education in British, the problem of over-nationalistic and over-controlled knowledge can be easily eliminated.

However, the national curriculum for history was canceled in the 1990s with the government concerning practical skills more important than history. The short applying time for constructivism thus fails to prove its long-standing educational advantages and efficiency in achieving the aim of more individuals thinking critically. Though the evolution of the history education curriculum is only temporary in Britain, according to Hanna Schissler and Yasemin Nuhoglu Soysal, the European countries are constantly adjusting their current history textbooks and national curricula [1][3]. Due to 'today's world of increasing globalization, European countries altered the narratives used in their textbooks to fit in today's focus on minority groups and communities [9]. It is clear that the nations are pushing their efforts in balancing the objectives of history education with more attention focusing on interpreting the history knowledge from the world perspective. Constructivism in European history education offers the learners 'opportunity to learn about the intended history curriculum in one or more discrete nations in Europe' [9]. To conclude, the progress that nations, with the example of many European countries, are making in applying constructivism to history education curricula have the potential to balance the conflicts aforementioned. 


\subsection{The Role of Textbooks and Extra-Curriculum Activities in History Education}

Besides the theory for history education, textbooks and extra-curriculum activities of learners also correspond to the curriculum to a large extent. The knowledge inside nation-controlled textbooks directly represents what kind of interpretation to the past events does the country or government wishes to represent to the society. Nevertheless, the knowledge presented in textbooks may be proved to be wrong, or wrongly interpreted. Because of this, several countries constantly edit and alter the textbooks in relatively more objective perspectives to ensure a balance for not overly educating the citizens to become nationalistic. Examples to further illustrate this include various European countries. For Ukraine history textbooks in the early 20th century, according to Korostelina, 'history textbooks described customs and traditions and focused attention on artists, poets and writers' while at the same time 'completely deny Ukrainian national character' [7]. As a newly developed country, Ukraine in the 20th century depicted all the knowledge in history education in the perspective of not a nation, but part of the Soviet Union. In this condition, national identity was largely hampered from developing as all the citizens were taught with knowledge denying the existence of Ukrainian's own culture. However, as soon as scholars and experts in Ukraine realized their current situation of the need to 'develop its own history', textbooks were edited to identify the differences between Ukrainian culture and Russian, or Soviet Union's, culture and offered the citizens a clearer overview of their own country's identity.

Besides Ukraine, North Ireland is another example. Just as Korostelina stated, North Ireland 'from a biased presentation of history associated with the mobilized form of identity to a reduction of prejudice associated with the reflected form of identity' [5]. Before, 'the official history education in Northern Ireland in the 1920s aimed to develop a strong British national identity and loyalty to the constitution of Northern Ireland'; in the 1940s, leaders of North Ireland started to question whether the way that history textbooks interpret British culture would hinder the development of North Ireland's own culture. The aforementioned conference in the 1960s was thus led by the discussion between parties in North Ireland and more objective knowledge thus derived and was introduced into the history textbooks.

From these two examples, it's clear that countries that adjust the national curriculum and textbooks corresponding to social questions or problems may neutralize the over-nationalistic perspectives into a more objective view. From this way, learners receive more correctly interpreted historical facts and individual thinking may thus derive. Not only do textbooks and curricula consist of the entire history education system for learners, but extra-curriculum activities are also important in constructing history knowledge for the students. María-Luisa Sarti, concluding and reviewing the book History Education and the Construction of National Identities, stated that 'students build intuitive understandings of history through interactions with others in order to adapt to their group' [4]. As 'school is not the only agent of social influence on individual historical knowledge construction', the social condition and cultural atmosphere greatly influence the learners' understanding and interpreting levels as well as ethic choices. In correlation to this point raised by Milligan, Gibson, and Peck, Michael Fordham raised the Tradition based inquiry (2016) out of MacIntyre's Three Rival Versions of Moral Enquiry [2] stating that applying the knowledge learned from the past traditions to the present work and acquiring the knowledge of the relationship between past and future, the latter of which is concluded from the tradition are great components of tradition-based inquiry. The introduction of the 1991 National Curriculum in England and Wales and the common General Certificate of Secondary Education marked the step of integrating disciplinary concepts and practices into the subject and model of history education [8]. illustrate the practical usage of tradition-based inquiry into history education. Though potential challenges may derive from the specific inquiry and theory, the concept of the importance of extra-curriculum factors that contribute to achieving the objectives of history education still plays an essential role in consisting the most suitable education methodology for history.

\section{CONCLUSION}

It is undoubted that history education is one of the most important areas of education in contributing to the construction of individual, social, and national identity. Though inevitable conflicts between objectives of history education may be explicit and hard to overcome, scholars, experts, nations have been trying to innovate the history education curricula all the time. The question of how to balance the conflicting goals of history education is answered by this study. With the analysis into different countries, including Ukraine, Britain, North Korea, and so on, specific patterns and theories of usage are found and further discussed. To conclude and reach out for a solution, the theory of constructivism may be applied to a larger extent by countries for their history education curricula. Besides, the edition and reservation of textbooks in nation-controlled curricula should be ensured to correspond to a more objective and global perspective. Last but not least, extra-curriculum factors, with the example of tradition-based inquiry, may also be considered when viewing the efficiency of history education. Though the current situation for 
history education in most countries is hard to conclude as a whole, the essential core and meaning of this academic discipline are constant and uniform. With great challenges and difficulties in achieving a balance in this conflicting academic field, more attention and efforts should be paid to conquer the setbacks.

\section{ACKNOWLEDGMENT}

First and foremost, I would like to show my deepest gratitude to my teachers and professors in my project, who have provided me with valuable guidance in every stage of the writing of this thesis. Further, I would like to thank all my friends and classmates for their encouragement and support. Without all their enlightening instruction and impressive kindness, I could not have completed my thesis.

\section{REFERENCES}

[1] T. Bertilotti, \& S. Mannitz, Projections of Identity in French and German History and Civics Textbooks. In Soysal Y. \& Schissler H. (Eds.), The Nation, Europe, and the World: Textbooks and Curricula in Transition, 2005(pp. 13-34). Berghahn Books. Retrieved March 7, 2021, from http://www.jstor.org/stable/j.ctt1btbwcq.6

[2] A. MacIntyre (2008). Three rival versions of moral enquiry encyclopaedia, genealogy, and tradition. Notre Dame, Ind: University of Notre Dame Press, 2008.

[3] H. Schissler, \& Y.H. Soysal, The Nation, Europe, and the world: Textbooks and curricula in transition. New York, NY: Berghahn Books, 2005.

[4] A. Milligan, L. Gibson, \& C. L. Peck, C. L, Enriching ethical judgments in history education. Theory \& Research in Social Education, 2017 46(3),449-479.doi:10.1080/00933104.2017.138966 5

[5] K. Korostelina, History education and social identity. Identity 2018, 8(1), 25-45. doi:10.1080/15283480701787327

[6] H. Cooper, International perspectives on history education.2018, 3-13, 38(3), 219-223. doi:10.1080/03004279.2010.497268

[7] K. Korostelina, Shaping unpredictable PAST: National identity and history education in Ukraine. National Identities,2011, 13(1), 1-16. doi:10.1080/14608944.2010.508817

[8] M. Fordham, Tradition, authority and disciplinary practice in history education. Educational Philosophy and Theory, 2016, 49(6), 631-642. doi:10.1080/00131857.2015.1135777
[9] H. Landorf, The nation, Europe and the world: Textbooks and curricula in transition. Compare: A Journal of Comparative and International Education, 2010, 40(1), 133-134. doi:10.1080/ 03057920903425671

[10] A. Macintyre, \& J. Dunne, Alasdair MacIntyre on Education: In dialogue with JOSEPH DUNNE. Journal of Philosophy of Education, 2002, 36(1), 1-19. doi:10.1111/1467-9752.00256

[11] M. Stobart, The importance of minority education rights in the new europe. International Journal on Minority and Group Rights, 1996, 4(2), 156-162. doi:10.1163/15718119620907175

[12] M. E. Smith. Reckoning with the past: Teaching history in Northern Ireland. Lanham: Lexington Books, 2005. 